Boletín de la Sociedad Geológica Mexicana

VOLUMEN 67, NÚM. 1, 2015, P. 103-112

\title{
A new species of Diaulax Bell, 1863 (Brachyura: Dialucidae) in the Early Cretaceous of the Rosablanca Formation, Colombia
}

\author{
Arley de Jesús Gómez-Cruz¹, Hermann D. Bermúdez², Francisco J. Vega ${ }^{3, *}$ \\ ${ }^{1}$ Universidad de Caldas, Facultad de Ciencias, Departamento de Ciencias Geológicas, Calle 65, No. 26-10, Manizales, Caldas, \\ Colombia. \\ ${ }^{2}$ Paleoexplorer S.A.S., Carrera 32A No. 25-10. Bogotá D.C., Colombia. \\ ${ }^{3}$ Instituto de Geología, UNAM, Ciudad Universitaria, Coyoacán, México DF 04510, Mexico. \\ *vegver@unam.mx
}

\begin{abstract}
The oldest record of the brachyuran Diaulax Bell, 1863 is based on the description of Diaulax rosablanca $\mathrm{n}$. sp. from the middle part of the Rosablanca Formation (Early Cretaceous, early Valanginian, Department of Santander, Colombia). This is also the oldest record for fossil crustaceans from Colombia. The new species is represented by numerous specimens showing ontogenic variation in size and shape, with adults becoming larger and wider at the anterior portion of carapace. Differences with the other five species of the genus are subtle but sufficient to erect a new species. The associated ammonites Lissonia riveroi (Lisson, 1907), Acantholissonia gerthi (Weaver, 1931) and Raimondiceras sp. confirm an age corresponding to the middle part of the early Valanginian. The paleoenvironment is interpreted as a shallow, restricted low-energy carbonate platform or lagoon within well-oxygenated warm waters. The outcrop includes other decapod remains, too incomplete to offer a preliminary identification.
\end{abstract}

Keywords: Brachyura, Dialucidae, Diaulax, ammonites, Valanginian, Colombia.

\section{Resumen}

El registro más antiguo del género Diaulax Bell, 1863 se basa en la descripción de Diaulax rosablanca n. sp. de la parte media de la Formación Rosablanca (Cretácico Temprano, Valanginiano temprano, Departamento de Santander, Colombia). El reporte representa también el registro más antiguo de crustáceos fósiles para Colombia. La nueva especie está representada por numerosos especímenes que muestran variación ontogénica en tamaño y forma, con adultos que presentan un caparazón más grande y ancho en la porción anterior. Las diferencias con las otras cinco especies del género son sutiles pero suficientes para proponer una nueva especie. Los ammonites asociados Lissonia riveroi (Lisson, 1907), Acantholissonia gerthi (Weaver, 1931) y Raimondiceras sp. confirman una edad correspondiente a la parte media del Valanginiano temprano. El paleoambiente es interpretado como una plataforma carbonatada restringida somera, de baja energía o una laguna con aguas bien oxigenadas. La localidad de estudio incluye restos de otros decápodos, muy incompletos para ofrecer una identificación preliminar.

Palabras clave: Brachyura, Dialucidae, Diaulax, ammonites, Valanginiano, Colombia. 


\section{Introduction}

The collection and description of Cretaceous crustaceans from Colombia have notably increased in recent years (Vega et al., 2007; Vega et al., 2010; Luque et al., 2013; Bermúdez et al., 2013), providing valuable information about the evolution and distribution of these organisms in tropical seas. Collections made from a new fossiliferous locality in the middle part of the Rosablanca Formation (Lower Cretaceous) produced numerous specimens of a new species of Diaulax Bell, 1863, Diaulax rosablanca n. sp. (Brachyura: Dialucidae). The new discovery and subsequent description herein represents the oldest record and first report of the genus in South America.

\section{Geographic and stratigraphic setting}

The studied locality is located in Loma del Corral, near the Bucaramanga - Zapatoca road, Department of Santander, about $260 \mathrm{~km}$ northeast of Bogotá D.C., Colombia (Figure 1). In this area, the Early Cretaceous deposits represent the beginnings of a regional transgressive event, which deposited mudstones and marine limestones of the Rosablanca Formation over the fluvial sandstones of the Los Santos Formation. Outcrop exposures are located in the middle part of the Rosablanca Formation within the Zapatoca Syncline, a part of the hanging wall of Suarez Fault (Figure 2).

The Rosablanca Formation consists of Early Cretaceous (Valanginian - Hauterivian) mudstones and marine limestones (Morales, 1958; Guzmán, 1985; Rojas-Briceño and Patarroyo, 2009). In the studied area the formation consists of interbedded mudstones, wackestones, packstones and dolomites (which predominate towards the base of unit), fossiliferous mudstones and marls (which predominate towards the middle part of unit) and by arenaceous limestones, fossiliferous sandstones and lumachellic limestones (which predominate in the upper unit) (Figure 3 ). The formation is highly fossiliferous with an abundant fauna of ostracods, foraminifera, mollusks and echinoderms.

Abundant Diaulax specimens were collected within the middle unit, although occasional specimens were collected within the lower and upper units. The associated fauna includes other crustacean remains, gastropods, ammonites and articulated bivalves. There is no evidence of
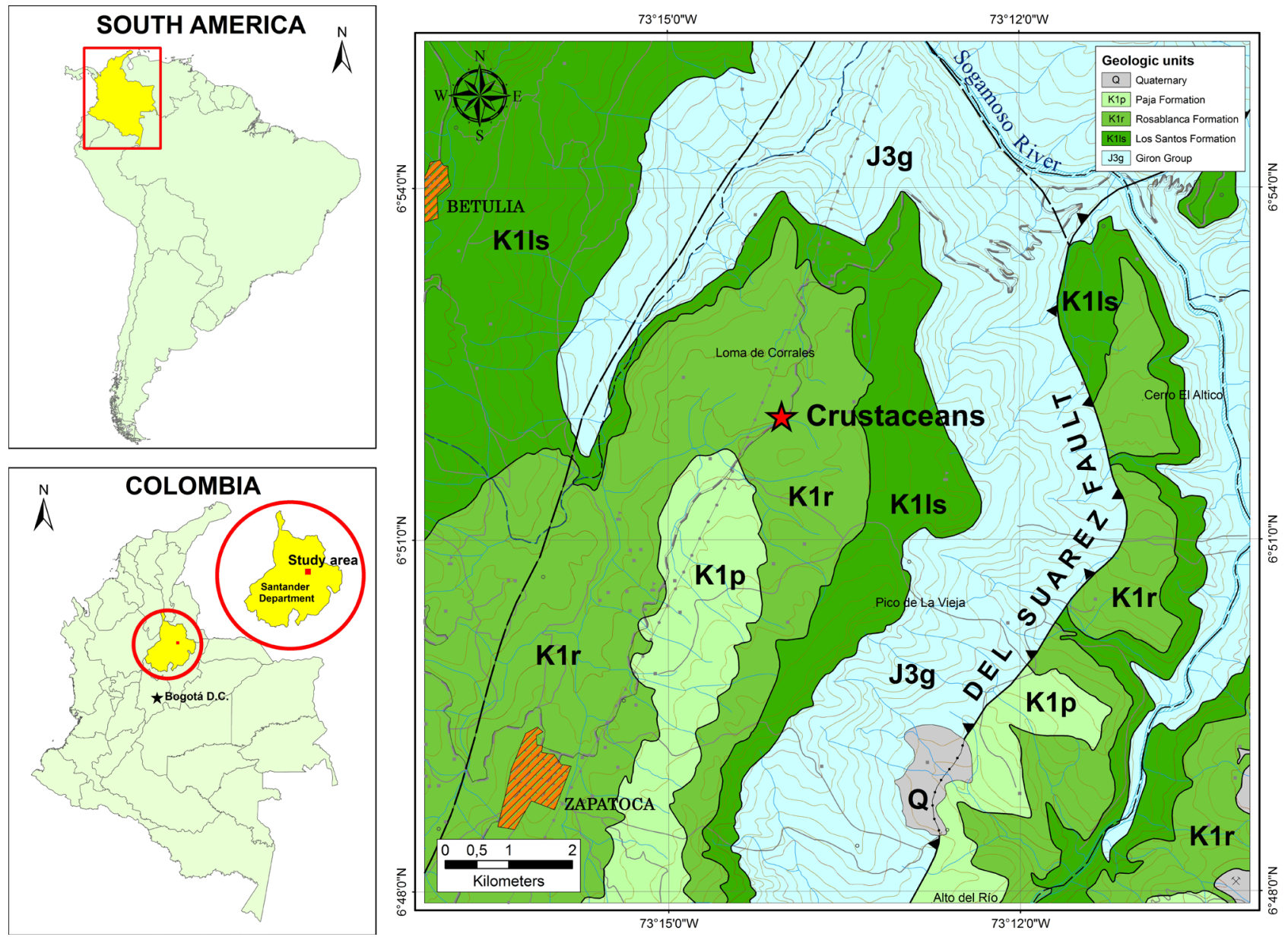

Figure 1. Geologic map with location of fossiliferous locality, north of Zapatoca, Santander Department, Colombia (Geological base from Ward et al., 1973). 

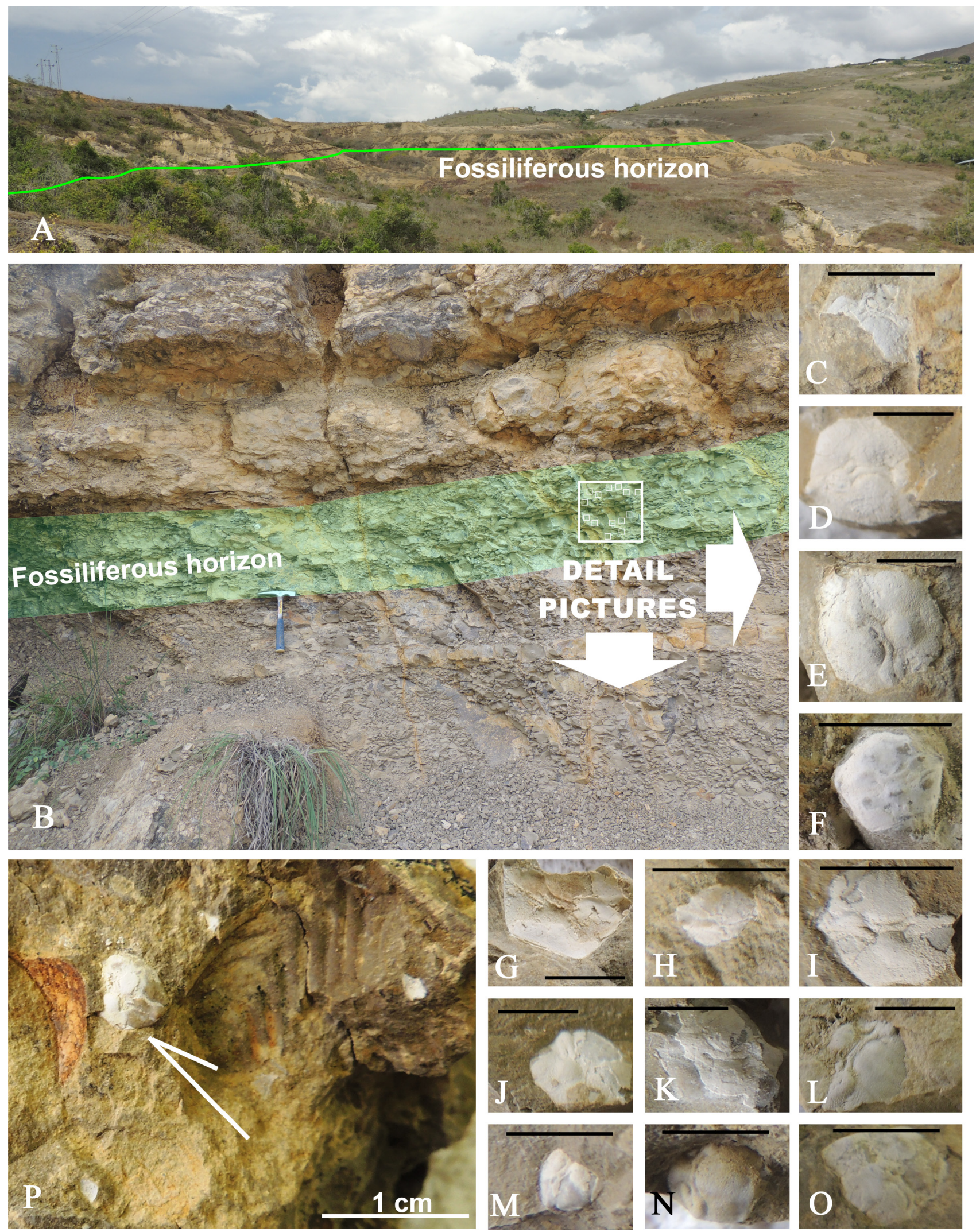

Figure 2. Composite view of the Rosablanca Formation outcrop, north of Zapatoca, with position of fossiliferous locality. A, Panoramic view of studied outcrp, with approximate position of crab-bearing fossiliferous horizon (green line). B, Close up of outcrop with fossiliferous horizon (green) and approximate position where multiple crab specimens were collected (arrows). C-P, Diaulax rosablanca $\mathrm{n}$. sp. specimens in situ, scale bars $=1 \mathrm{~cm}$. 


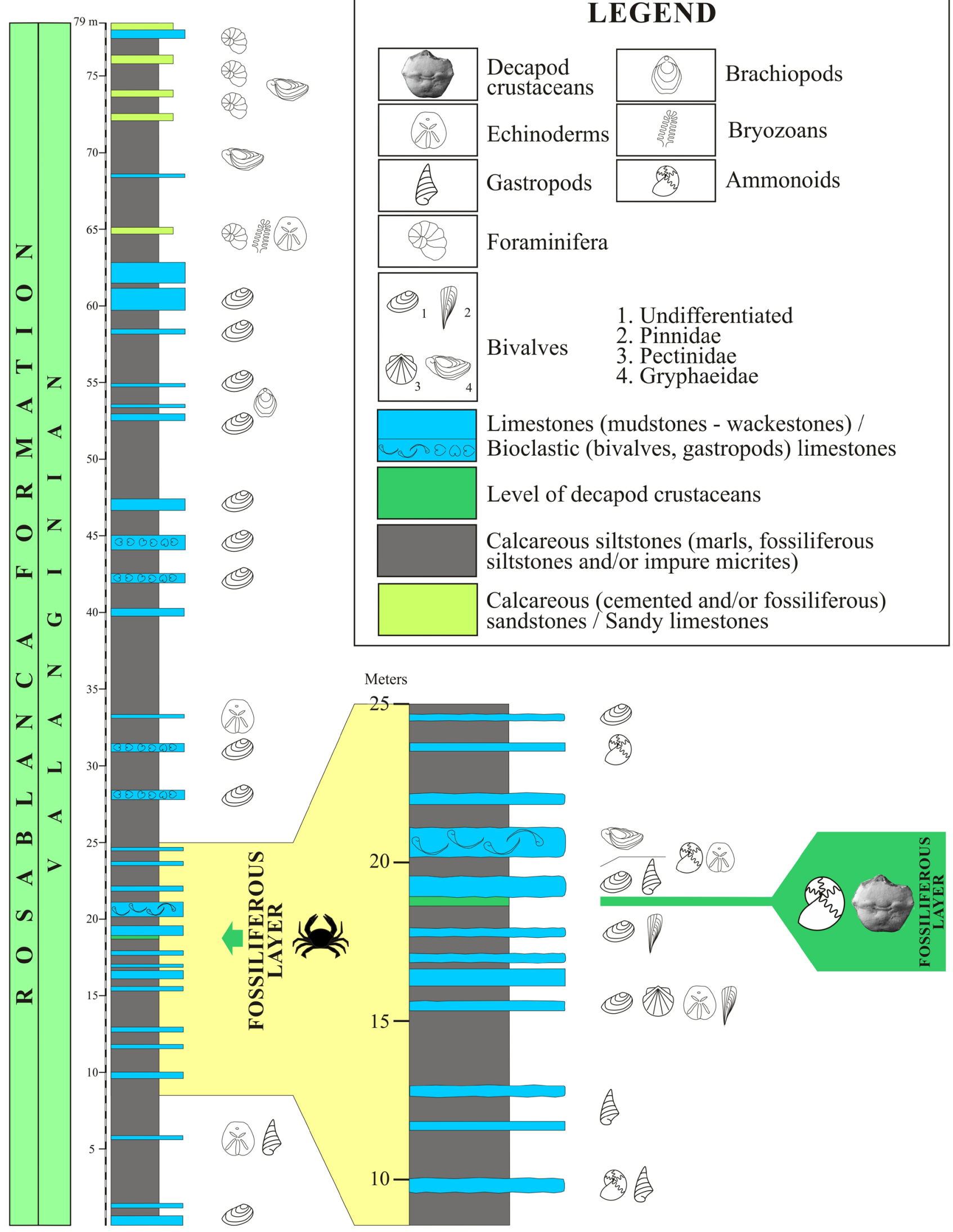

Figure 3. Stratigraphic section of the middle part of the Rosablanca Formation at study locality, with position of fossiliferous level. 


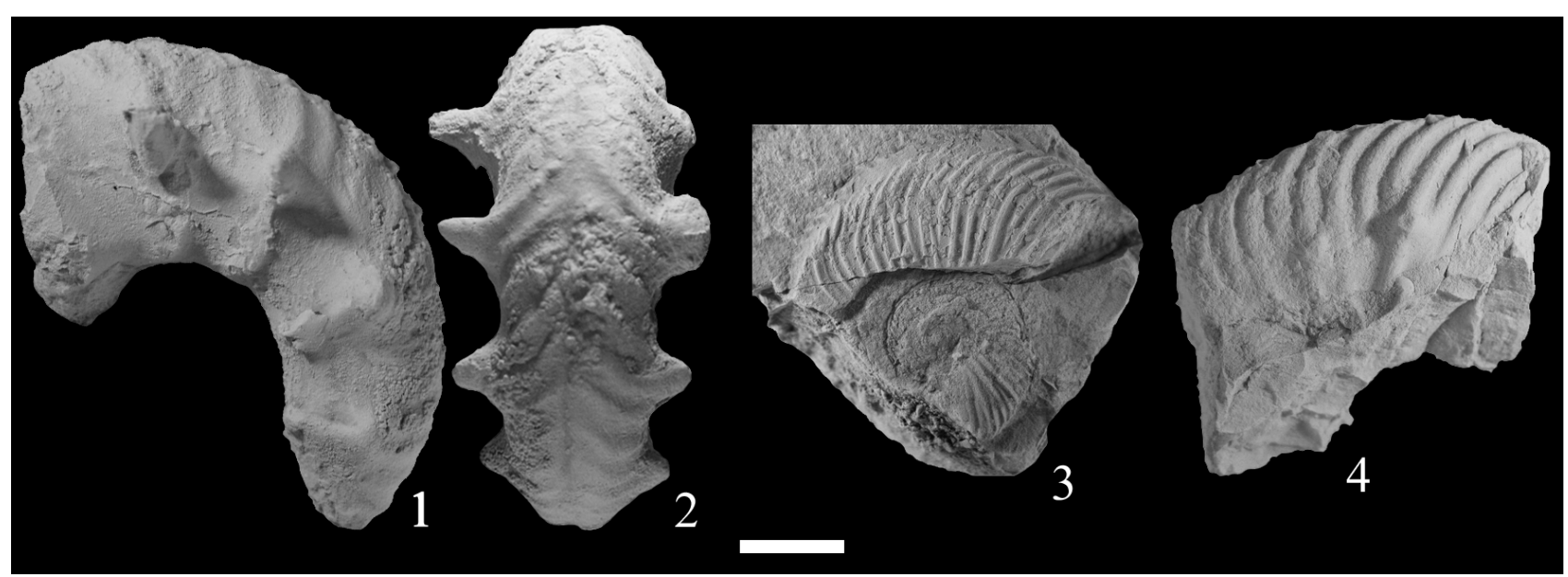

Figure 4. 1-2, Acantholissonia gerthi (Weaver, 1931), lateral and ventral views of specimen CAL 4141-4. 3, Lissonia riveroi (Lisson, 1907), lateral view of specimen CAL 4141-2. 4, Raimondiceras sp., lateral view of specimen CAL 4141-3. Scale bar $=1 \mathrm{~cm}$.

reworking or abrasion of the fossils. The paleoenvironment is interpreted as a shallow, restricted low-energy carbonate platform or lagoon within well-oxygenated warm waters.

\subsection{Ammonite biostratigraphy}

Ammonites are present in the study area. They include Lissonia riveroi (Lisson, 1907), Acantholissonia gerthi (Weaver, 1931) and Raimondiceras sp. (Figure 4). The ammonoid assemblage composed of $L$. riveroi and $A$. gerth $i$ has been documented in Argentina and has been assigned to the L. riveroi Zone (e.g. Aguirre-Urreta and Rawson, 1999; Aguirre-Urreta et al., 2005, 2007; Rawson, 2007), which has been dated to the middle part of the early Valanginian. Therefore, we assign an age corresponding to the middle part of the early Valanginian to the Colombian ammonite assemblage.

Specimens are deposited at the Paleontological Collection of Caldas University, Facultad de Ciencias Exactas y Naturales, Departamento de Ciencias Geológicas, Calle 65 No. 26-10, Manizales, Colombia, under the acronym CAL.

\section{Systematic palaeontology}

Order Decapoda Latreille, 1802

Infraorder Brachyura Linnaeus, 1758

Superfamily Dromioidea de Haan, 1833

Family Dialucidae Wright and Collins, 1972

Genus Diaulax Bell, 1863

Type species. Diaulax carteriana Bell, 1863 [=D. oweni (Bell, 1850)].

Other species. Diaulax oweni (Bell, 1850); D. feliceps Wright and Collins, 1972; D. roddai Bishop, 1983; D. millerae Bishop, 1992; D. yokoii Collins, Kanie and
Karasawa, 1993.

\section{Diaulax rosablanca $\mathrm{n}$. sp.} Figure 5

Diagnosis. Octagonal-shaped dorsal carapace, slightly wider than long, widest part at epibranchial region. Rostrum triangular. Rimmed, large orbital sockets oval. Fronto-orbital width $\sim 75 \%$ of maximum width. Concavely rimmed anterolateral margin slightly convex. Posterolateral margin straight in middle part. Rimmed posterior margin straight to slightly concave, $\sim 45 \%$ of maximum width. Epigastric, protogastric and hepatic regions undifferentiated. Pyriform mesogastric region. Longitudinally narrow meta-/ urogastric region slightly concave forward. Epibranchial with prominent node. Mesobranchial region strongly inflated. Metabranchial regions connect axially. Cardiac region hexagonal. Subhepatic region inflated. Cervical groove straight and deepest in axial portion. Postcervical groove parallels and equally strong as cervical groove. Branchiocardiac groove nearly straight. Circular granules present on gastric, cardiac, epibranchial, subhepatic, and mesobranchial regions. Female abdominal somites wide and short.

Description. Octagonal-shaped dorsal carapace usually slightly wider than long $(1 / \mathrm{w}=0.83, \mathrm{SD}=0.08, \mathrm{n}=59)$, widest part at epibranchial region, slightly-moderately convex transversely, moderately convex longitudinally, maximum measured width $12.8 \mathrm{~mm}$. Rostrum downturned obliquely, triangular with blunt, rounded at tip, lateral and smooth margins flared up, with sulcus in dorsal view. Rimmed, large orbital sockets oval. In dorsal view, upper orbital margin exhibiting nick toward outer edge; lower orbital margin slightly convex, extending beyond upper orbital margin in dorsal view. Upper and lower orbital margin end in blunt, forwardly directed spine. Frontoorbital width $\sim 75 \%$ of maximum width. Concavely rimmed 


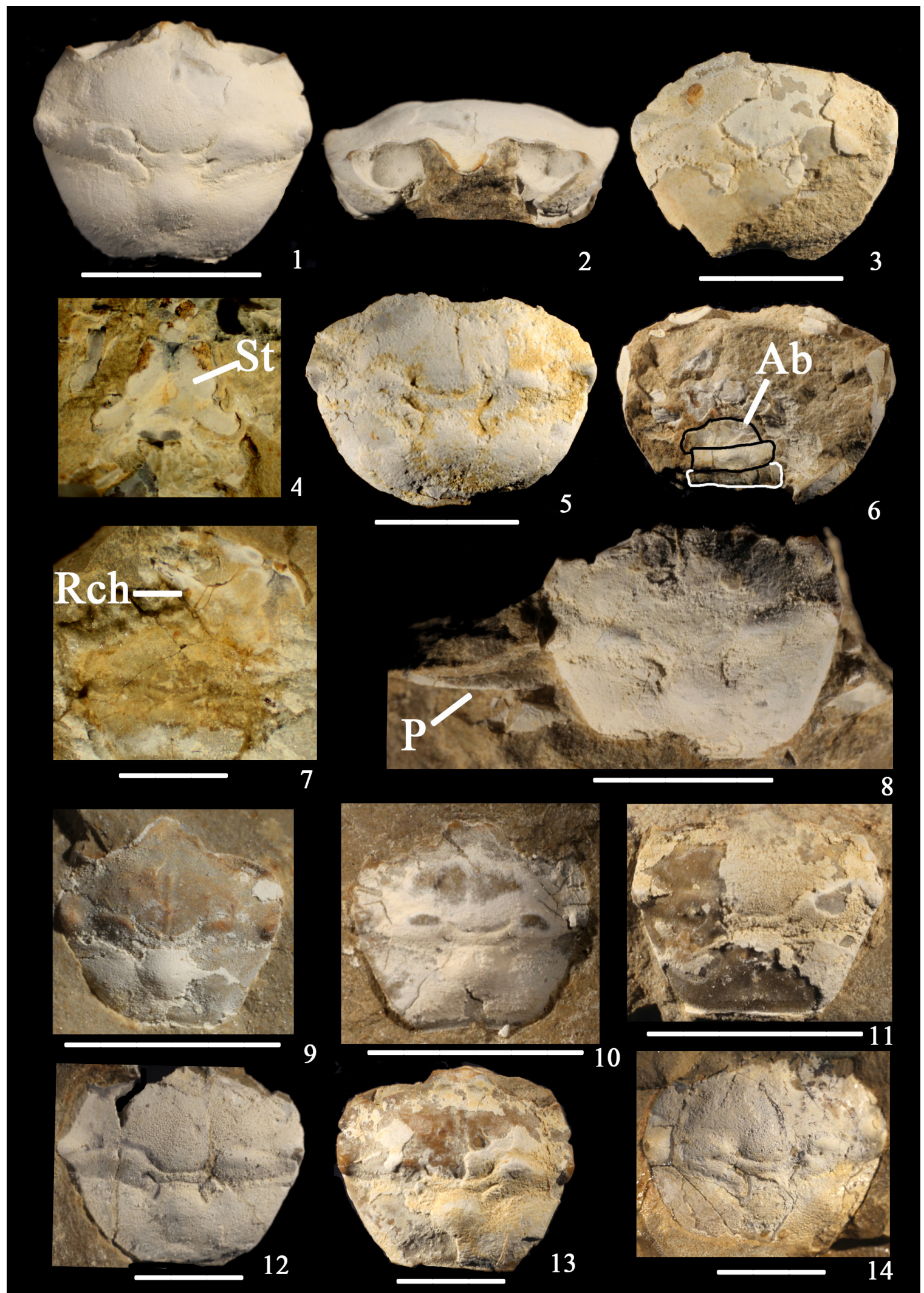

Figure 5. Diaulax rosablanca n. sp. 1, Dorsal view of holotype CAL 4141-8; 2, Frontal view of same specimen; 3, Dorsal view of paratype CAL 4141-9; 4, Ventral view of same specimen showing anterior portion of sternum (St); 5, Dorsal view of paratype CAL 4141-10; 6, Ventral view of same specimen, showing female abdominal somites (Ab); 7, Dorsal view of paratype CAL 4141-11, showing right chela (RCh); 8, Dorsal view of paratype CAL 4141-12, showing left middle pereiopods (P); 9, Dorsal view of paratype CAL 4141-13, juvenile specimen; 10, Dorsal view of paratype CAL 4141-14, juvenile specimen; 11, Dorsal view of paratype CAL 4141-15, juvenile specimen; 12, Dorsal view of paratype CAL 4141-16, middle-sized specimen; 13, Dorsal view of paratype CAL 4141-17, middle-sized specimen; 14, Dorsal view of paratype CAL 4141-18, large specimen. Scale bars $=0.5 \mathrm{~cm}$. 
anterolateral margin slightly convex, flaring upwards, with notch from intersection of cervical groove. Posterolateral margin straight in middle part, but convex near transition to anterolateral and posterior margins. Rimmed posterior margin straight to slightly concave, $\sim 45 \%$ of maximum width. Epigastric protogastric, and hepatic regions undifferentiated. Pyriform mesogastric region with narrow, longitudinal ridge nearly originating at cervical groove and continuing as mesogastric process. Longitudinally narrow meta-/urogastric region slightly concave forward. Epibranchial region characterized by prominent node. Mesobranchial region strongly inflated just posterior to cervical groove; less toward branchiocardiac groove. Metabranchial regions connect axially: intestinal region undifferentiated. Cardiac region hexagonal, with apex directed posteriorly, usually with three tubercles. Subhepatic region inflated. Cervical groove straight and deepest in axial portion, sinuous thereafter, intersects anterolateral margin, initially vertically oriented on lateral flank, then curves around subhepatic region below orbit. Postcervical groove parallels and equally strong as cervical groove, concave forward. Branchiocardiac groove nearly straight, shallower than axial parts postcervical and cervical grooves, intersects lateral margin just posterior to epibranchial node, then curves forward to join cervical groove. Circular granules present on gastric, cardiac, epibranchial, subhepatic, and mesobranchial regions. Granules on posterior part metabranchial region may appear elongated transversely. Female abdominal somites rectangular, narrow, short. Sternum triangular, sternite 3 narrow, subpentagonal; sternite 4 subtrapeoidal, much wider and longer than sternite 3; sternite 5 subpentagonal, episternites 5 subovate, elongated, posteriorly inclined. Right chela massive, height of palm about $85 \%$ of maximum carapace length; fixed finger triangular, half the length of palm; movable finger triangular, slightly wider at base than fixed finger. Meri of middle pereiopods long and slender.

Locality and stratigraphic position. Loma del Corral sector, near the Bucaramanga - Zapatoca road, Department of Santander, Colombia, about $260 \mathrm{~km}$ northeast of Bogotá D.C. middle part of the early Valanginian (Early Cretaceous).

Repository. 59 specimens, holotype CAL 4141-8, paratypes CAL 4141-9 to CAL 4141-66.

Measurements. Measurements for each specimen are given in Table 1.

Etymology. The trivial name alludes to the Rosablanca Formation, lithostratigraphic unit.

Discussion. Jagt et al. (2010) considered Diaulax to be represented by five species: $D$. oweni (Bell, 1850); $D$. feliceps Wright and Collins, 1972; D. millerae Bishop, 1992; D. roddai Bishop, 1983 and D. yokoii Collins, Kanie and Karasawa, 1993. D. carteriana Bell, 1863 is a junior subjective synonym of $D$. oweni, according to Wright and Collins, 1972.

Diaulax oweni Bell, 1850 from the Cenomanian of
Table 1. Measurements for studied specimens of Diaulax rosablanca $\mathrm{n}$. sp.

\begin{tabular}{|c|c|c|}
\hline Specimen & Length (mm) & Width (mm) \\
\hline CAL 4141-8 & 7.6 & 8.7 \\
\hline CAL 4141-9 & 8.9 & 10 \\
\hline CAL 4141-10 & 9.3 & 11.7 \\
\hline CAL 4141-11 & 5.6 & 6.2 \\
\hline CAL 4141-12 & 7.6 & 9.1 \\
\hline CAL 4141-13 & 3.6 & 4 \\
\hline CAL 4141-14 & 5.1 & 5.7 \\
\hline CAL 4141-15 & 4.7 & 6.4 \\
\hline CAL 4141-16 & 8 & 8.9 \\
\hline CAL 4141-17 & 7.1 & 9.9 \\
\hline CAL 4141-18 & 10.2 & 12.1 \\
\hline CAL 4141-19 & 7.4 & 8.5 \\
\hline CAL 4141-20 & 9.8 & 10.8 \\
\hline CAL 4141-21 & 5.8 & 6.7 \\
\hline CAL 4141-22 & 4.6 & 4.5 \\
\hline CAL 4141-23 & 7.9 & 10.3 \\
\hline CAL 4141-24 & 9.1 & 10.8 \\
\hline CAL 4141-25 & 5.8 & 7 \\
\hline CAL 4141-26 & 11.6 & 14 \\
\hline CAL 4141-27 & 6.3 & 7.5 \\
\hline CAL 4141-28 & 10.4 & 11.5 \\
\hline CAL 4141-29 & 5.8 & 7.4 \\
\hline CAL 4141-30 & 3.8 & 3.3 \\
\hline CAL 4141-31 & 5.3 & 6.5 \\
\hline CAL 4141-32 & 6.4 & 8.2 \\
\hline CAL 4141-33 & 7.6 & 8.9 \\
\hline CAL 4141-34 & 9.2 & 10.8 \\
\hline CAL 4141-35 & 7.5 & 8.9 \\
\hline CAL 4141-36 & 6.9 & 9.3 \\
\hline CAL 4141-37 & 4.9 & 5.8 \\
\hline CAL 4141-38 & 7.3 & 9.3 \\
\hline CAL 4141-39 & 6.8 & 7.4 \\
\hline CAL 4141-40 & 3.2 & 3.2 \\
\hline CAL 4141-41 & 6.5 & 7.9 \\
\hline CAL 4141-42 & 5.9 & 7.3 \\
\hline CAL 4141-43 & 6 & 7.9 \\
\hline CAL 4141-44 & 5.8 & 7.8 \\
\hline CAL 4141-45 & 6 & 7.3 \\
\hline CAL 4141-46 & 6.9 & 9 \\
\hline CAL 4141-47 & 7.5 & 8.8 \\
\hline CAL 4141-48 & 5.6 & 7.2 \\
\hline CAL 4141-49 & 7.3 & 8.7 \\
\hline CAL 4141-50 & 5.8 & 6.6 \\
\hline CAL 4141-51 & 7.1 & 9.5 \\
\hline CAL 4141-52 & 8.6 & 9.3 \\
\hline CAL 4141-53 & 6.2 & 7.9 \\
\hline CAL 4141-54 & 5.7 & 8.7 \\
\hline CAL 4141-55 & 5.5 & 6.2 \\
\hline CAL 4141-56 & 6.6 & 7.3 \\
\hline CAL 4141-57 & 5.9 & 8.4 \\
\hline CAL 4141-58 & 5.7 & 6.7 \\
\hline CAL 4141-59 & 7.1 & 9.3 \\
\hline CAL 4141-60 & 5.2 & 7.5 \\
\hline CAL 4141-61 & 7.1 & 9 \\
\hline CAL 4141-62 & 5.9 & 8.5 \\
\hline CAL 4141-63 & 5 & 5.7 \\
\hline CAL 4141-64 & 8 & 9.1 \\
\hline CAL 4141-65 & 7.3 & 9.4 \\
\hline CAL 4141-66 & 10.5 & 12.8 \\
\hline
\end{tabular}


England has a wider carapace at the anterior fourth, the anterolateral margin lacks notches, two small tubercles are found on the protogastric region and it has a stronger cervical groove; D. feliceps Wright and Collins, 1972 from the Albian of England has a wider anterior margin and stronger cervical groove; D. millerae Bishop, 1992 from the Campanian of Delaware has a more elongated carapace with stronger branchiocardiac groove and well-defined dorsal carapace regions; D. roddai Bishop, 1983 from the Albian of Texas has a more elongated carapace with stronger cervical groove; D. yokoii Collins, Kanie and Karasawa, 1993 from the Santonian of Japan has a stronger protogastric process and well-defined carapace regions.

Diaulax? italica Beschin, Busulini, De Angeli and Tessier, 2007 from the early Eocene of Italy has a narrower carapace with stronger cervical and branchiocardiac grooves, and its affinity with Diaulax is uncertain.

The carapace on the new species becomes relatively wider compared to the length with ontogeny (Figure 6). A similar type ontogenetic variation was suggested by Klompmaker (2013) for Graptocarcinus texanus Roemer, 1887 and Klompmaker, Feldmann and Schweitzer (2012) for Distefania incerta (Bell, 1863), Eodromites grandis (von Meyer, 1857), Goniodromites laevis (Van Straelen, 1940) and Navarradromites pedroartali Klompmaker, Feldmann
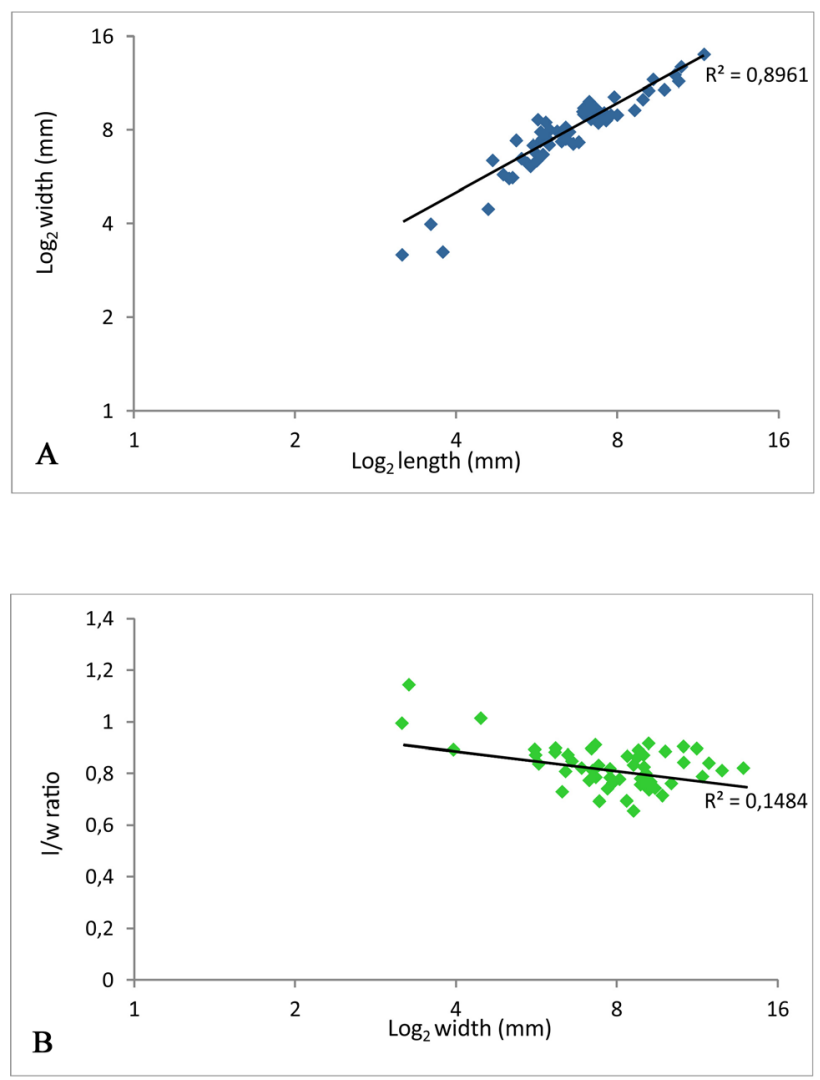

Figure 6. Morphometric analyses of the length and width of the carapace of Diaulax rosablanca n. sp. A, $\log _{2}$ of width plotted against length. B, Length/width ratio plotted against $\log _{2}$ of the width. and Schweitzer (2012).

Occurrence of a well-represented population of $D$. rosablanca $\mathrm{n}$. sp. might be the result of either a mass mortality event or an increase of population members as a result of favorable conditions. Along with the numerous specimens of the new species, incomplete remains of other crustacean taxa are found, such as disarticulated chelae, too slender to belong to Diaulax. Most specimens of D. rosablanca n. sp. are represented only by dorsal carapaces, which suggest a certain amount of transport from the place where specimens died however there is no evidence of reworking or transportation of the other fossils from this locality therefore it is possible the specimens represent molts. A relatively rapid burial of the specimens is suggested, since most carapaces do not show traces of abrasion.

Diaulax rosablanca $\mathrm{n}$. sp. represents the oldest record for the genus and the first record in South America, where a center for origin of primitive Eubrachyura has been proposed (Luque et al., 2013).

Other crustacean remains (Figure 7), found along with specimens of the new species, indicate the locality has potential for future reports on other associated decapod species.

\section{Acknowledgements}

Fieldwork of H. D. Bermúdez and F. J. Vega was funded

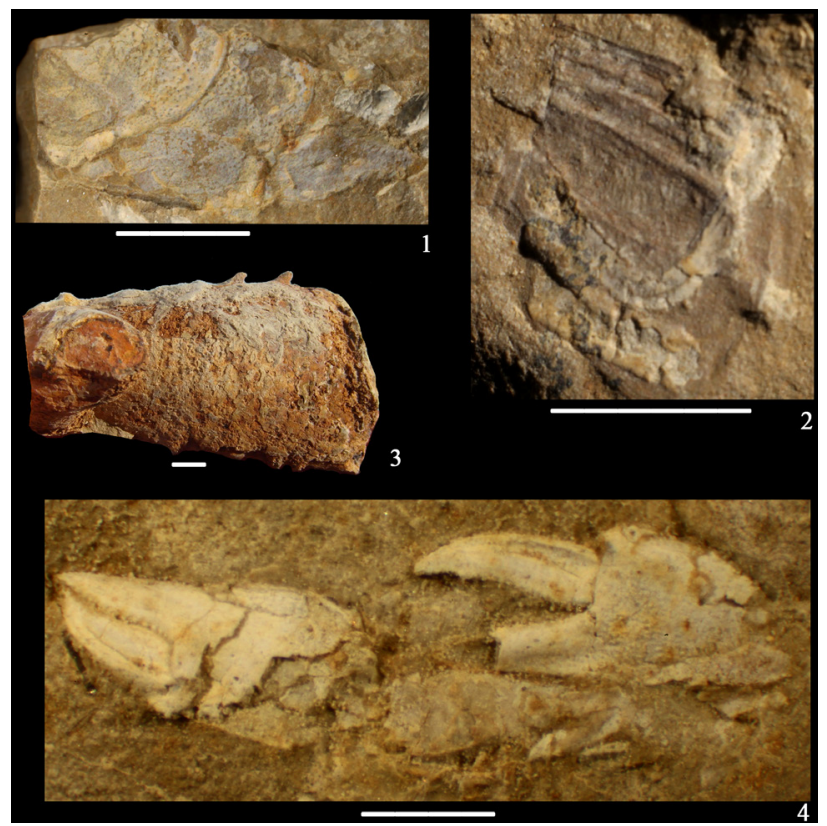

Figure 7. Associated decapod remains found in the same layer where specimens of Diaulax rosablanca $\mathrm{n}$. sp. were collected. 1, 2, Cephalothorax and uropods of a possible mecochirid specimens CAL 4141-67 and CAL 4141-68; 3, Hoploparia sp., left carpus and palm, specimen CAL 4141$69 ; 4$, Right and left chelae of a possible homoloid crab, specimen CAL 4141-70. Scale bars $=0.5 \mathrm{~cm}$. 
by the research group of Paleoexplorer S.A.S, as part of the project "Fossil crustaceans of Colombia". Thanks to the staff of Paleoexplorer, geologist J. A. Rey, who collaborated on the collection of fossils during one of the visits to the fossiliferous locality in 2013, as well as the GIS Engineer Liliana Bolívar, for the elaboration of the cartographic material and the stratigraphic column. J. A. Moreno-Bedmar (Instituto de Geología, UNAM, Mexico) and M. Company (Universidad de Granada, Spain) helped with ammonite biostratigraphy. Support and advice of Adiël Klompmaker (Florida Museum of Natural History) is highly appreciated. Our sincere gratitude to Alessandro Garassino (Museo di Storia Naturale, Milano, Italy), Matus Hyžný (Department of Geology and Palaeontology, Faculty of Natural Sciences, Comenius University, Slovakia) and Torrey Nyborg (Loma Linda University) for detailed review and suggestions to improve the original manuscript.

\section{References}

Aguirre-Urreta, M.B., Rawson, P.F., 1999, Stratigraphic position of Valanginites, Lissonia and Acantholissonia in the Lower Valanginian (Lower Cretaceous) ammonite sequence of the Neuquén basin, Argentina, in Olóriz, F., Rodríguez-Tovar, R. (eds), Advancing Research on Living and Fossil Cephalopods: New York, Kluwer Academic/Plenum Publishers, 521-529.

Aguirre-Urreta, M.B., Rawson, P.F., Concheyro, G.A., Bown, P.R., Ottone, E.G., 2005, Lower Cretaceous (Berriasian-Aptian) biostratigraphy of the Neuquén Basin, in Veiga G.D., Spalletti, L.A., Howel, J.A., Schwarz, E. (eds.), The Neuquén Basin: A Case Study in Sequence Stratigraphy and Basin Dynamics: Geological Society of London, Special Publication 252, 57-81.

Aguirre-Urreta, M.B., Mourgues, F.A., Rawson, P.F., Bulot, L.G., Jaillard, E., 2007, The Lower Cretaceous Chañarcillo and Neuquén Andean basins: ammonoid biostratigraphy and correlations: Geological Journal, 42, 143-173.

Bell, T., 1850, Notes on the Crustacea of the Chalk Formation, in Dixon, F. (ed.), The geology and fossils of the Tertiary and Cretaceous formations of Sussex: London, Brown, Green and Longmans, 344-345.

Bell, T., 1863, A Monograph of the Fossil Malacostracous Crustacea of Great Britain, Pt. II, Crustacea of the Gault and Greensand: Palaeontographical Society Monograph, London.

Bermúdez, H.D., Gómez-Cruz, A.J., Hyžný, M., Moreno-Bedmar, J.A., Barragán, R., Moreno-Sánchez, M., Vega, F.J., 2013, Decapod crustaceans from the Cretaceous (Aptian-Albian) San Gil Group in the Villa de Leyva section, central Colombia: Neues Jahrbuch für Geologie und Paläontologie Abhandlungen, 267, 255-272.

Beschin, C., Busulini, A., De Angeli, A., Tessier, G., 2007, I Decapodi dell'Eocene Inferiore di Contrada Gecchelina (Vicenza - Italia settentrionale) (Anomura e Brachiura): Museo di Archeologia e Scienze Naturali "G. Zannato": Montecchio Maggiore (Vicenza), 9-76.

Bishop, G.A., 1983, Fossil decapod crustaceans from the Lower Cretaceous, Glen Rose Limestone of central Texas: Transactions of the San Diego Society of Natural History, 20, 27-55.

Bishop, G.A., 1992, A new Cretaceous crab Diaulax millerae (Crustacea: Decapoda), from the northern Atlantic Coastal Plain, U.S.A: Proceedings of the Biological Society of Washington, 105, 555-561.

Collins, J.S.H., Kanie, Y., Karasawa, H., 1993, Late Cretaceous crabs from Japan: Transactions and Proceedings of the Palaeontological Society of Japan, (new series), 172, 292-310.

de Haan,W., 1833-1850, Crustacea, pp. i-xvii, i-xxxi, ix-xvi, 1-243, pls. AJ,
L-Q, 1-55, circ. table 2, in, von Siebold, P.F. (ed.), Fauna Japonica sive Descriptio Animalium, quae in Itinere per Japoniam, Jussu et Auspiciis Superiorum, qui summum in India Batava Imperium Tenent, Suscepto, Annis 1823-1830 Collegit, Notis, Observationibus et Adumbrationibus Illustravit. J. Müller et Co., Lugduni Batavorum [= Leyden].

Guzmán, G., 1985, Los Griferidos Infracretácicos Aetostreon couloni y Ceratostreon boussingaulti, de la Formación Rosablanca, como Indicadores de oscilaciones marinas. Proyecto Cretácico: Publicaciones Geológicas especiales del Ingeominas, 16, Capítulo XI, 1-16.

Jagt, J.W.M., Fraaije, R.H.B., Van Bakel, B.W.M., Artal, P., 2010, Necrocarcinus ornatissimus Forir, 1887, and Prehepatus werneri Fraaye \& Collins, 1987 (Upper Maastrichtian, The Netherlands) revisited, with Notes on other Cretaceous dynomenid crabs (Decapoda, Brachyura): Crustaceana Monographs, 11, 173-195.

Klompmaker, A.A., 2013, Extreme diversity of decapod crustaceans from the mid-Cretaceous (late Albian) of Spain: implications for Cretaceous decapod paleoecology: Cretaceous Research, 41, $150-185$.

Klompmaker, A.A., Feldmann, R.M., Schweitzer, C.E., 2012, A hotspot for Cretaceous goniodromitids (Decapoda, Brachyura) from reef associated strata in Spain: Journal of Crustacean Biology, 32, 780-801.

Latreille, P.A., 1802-1803, Histoire naturelle, générale et particulière, des Crustacés et des Insectes: Paris, F. Dufart, 3, 1-468.

Linnaeus, C. [von]., 1758, Systema Naturae per Regna tria Naturae, secundum classes, ordines, genera, species, cum characteribus, differentiis, synonymis, locis (ed. 10) 1: 1-824. Laurentii Salvii, Holmiae [= Stockholm].

Lisson, C.I., 1907, Contribución a la Geología de Lima y sus alrededores: Lima, Gil, 1-123.

Luque, J., Feldmann, R.M., Schweitzer, C.E., Karasawa, H., Jaramillo, C., 2013, On the origin and evolution of true crabs: insights from northern South America: Geological Society of America, Abstracts with Programs, 45, 459.

Morales, L.G., 1958, General geology and oil occurrences of the Middle Magdalena Valley, Colombia, in Weeks, L.G. (ed.), Habitat of Oil: A Symposium: Tulsa, Oklahoma, American Association of Petroleum Geologists, 641-695.

Rawson, P.F., 2007, Global relationships of Argentine (Neuquén Basin) Early Cretaceous ammonite faunas: Geological Journal, 42, 175-183.

Roemer, F.A., 1887, Graptocarcinus texanus, ein Brachyure aus der Kreide von Texas: Neues Jahrbuch für Mineralogie, Geologie, und Paläontologie, 1887, 173-176.

Rojas-Briceño, A., Patarroyo, P., 2009, Occurrence of Sellithyris sella (Brachiopoda) in the Rosablanca Formation, Boyacá-Colombia: Boletín de Geología, Universidad Industrial de Santander, 31, 129-132.

Van Straelen, V., 1940, Crustacés Décapodes nouveaux du Crétacique de la Navarre: Bulletin du Musée Royal d'Histoire Naturelle de Belgique, 16, 1-5.

Vega, F.J., Nyborg, T.G., Rojas, A., Patarroyo, P., Luque, J., PorrasMúzquiz, H., Stinnesbeck, W., 2007, Upper Cretaceous Crustacea from Mexico and Colombia: common faunas and environments during Turonian times: Revista Mexicana de Ciencias Geológicas, $24,403-422$.

Vega, F.J., Nyborg, T., Kovalchuk, G., Luque, J., Rojas-Briceño, A., Patarroyo, P., Porras-Múzquiz, H., Armstrong, A., Bermúdez, H., Garibay, L., 2010, On some Panamerican Cretaceous crabs (Decapoda: Raninoida): Boletín de la Sociedad Geológica Mexicana, $62,263-279$.

von Meyer, H., 1857, Briefliche Mitteilungen: Jahrbuch für Mineralogie, Geologie, Geognosie und Petrefaktenkunde, 556.

Ward, D.E., Goldsmith, R., Jimeno, A., Cruz, J., Restrepo, H., Gómez, E., 1973, Mapa geológico del Cuadrángulo H-12 Bucaramanga, 1:100000: Bogotá, INGEOMINAS, 1 mapa. 
Weaver, C.E., 1931, Paleontology of the Jurassic and Cretaceous of West Central Argentina: Memories of the University of Washington, 1, $1-469$.

Wright, C.W., Collins, J.S.H., 1972, British Cretaceous crabs: Palaeontographical Society Monographs, 126 (533), 1-113.

Manuscript received: November 12, 2014

Corrected manuscript received: November 26, 2014.

Manuscript accepted: November 30, 2014. 